\title{
Is There Pandemic Vitamin D Deficiency in the Black Population? A Review of Evidence
}

\author{
Ria S. Roberts ${ }^{1, \#}$, Fafa Huberta Koudoro ${ }^{1, \#}$, Mark S. Elliott ${ }^{2}$ and Zhiyong Han ${ }^{2, *}$ \\ ${ }^{I}$ The George Washington University School of Medicine and Health Sciences, Washington, DC, USA \\ ${ }^{2}$ Department of Biochemistry and Molecular Medicine, The George Washington University School of Medicine and \\ Health Sciences, Washington, DC, USA
}

\begin{abstract}
Although 1,25-dihydroxyvitamin D [1,25(OH) $\left.)_{2} \mathrm{D}\right]$ is the biologically active form of vitamin $\mathrm{D}$, measurement of the total serum 25-hydroxyvitamin $\mathrm{D}[25(\mathrm{OH}) \mathrm{D}]$ level is the gold standard used to define vitamin D status. Currently, it is widely accepted that serum $25(\mathrm{OH}) \mathrm{D}$ levels below $20 \mathrm{ng} / \mathrm{ml}$ defines vitamin D deficiency. According to this definition, there appears to be pandemic vitamin D deficiency in the Black population. However, there is no evidence of higher-thannormal rates of common complications and symptomology of true vitamin D deficiency in the Black population. What is going on? We researched the MEDLINE databases to find studies, from 1967 to present, that directly compare between Blacks and Caucasians the following: serum vitamin D level, serum calcium level, serum parathyroid hormone level, bone mineral density and health, and non-skeletal risks associated with vitamin D deficiency. The available studies consistently show that Blacks tend to have serum $25(\mathrm{OH}) \mathrm{D}$ levels in the deficient range while their serum $1,25(\mathrm{OH})_{2} \mathrm{D}$ level is similar to, if not even slightly higher than that of Caucasians, and that the serum $\mathrm{Ca}^{2+}$ level in Blacks is virtually identical to that in Caucasians. Therefore, it appears that the serum 25(OH)D level is not the best marker of vitamin D sufficiency or deficiency in Blacks. In the future, clinical evaluation of the vitamin D status in the Black population needs to consider other serum biomarkers such as $1,25(\mathrm{OH})_{2} \mathrm{D}$ and/or bioavailable $25(\mathrm{OH}) \mathrm{D}$.
\end{abstract}

Keywords: Black, deficiency, health, vitamin D.

\section{INTRODUCTION}

There are two sources of vitamin D for the human body: diet and biosynthesis of vitamin $\mathrm{D}$ in the skin upon exposure to adequate UV-B rays. As illustrated in Fig. (1), irradiation of the epidermis of the skin by UV-B rays induces a nonenzymatic reaction that converts 7-dehydrocholesterol to previtamin $\mathrm{D}$. The previtamin $\mathrm{D}$ then undergoes a slow, spontaneous conversion to vitamin $D_{3}$. Vitamin $D_{3}$ is transported out of the skin and undergoes two rounds of hydroxylation reactions; the first in the liver and the second in kidney. In the liver, vitamin $\mathrm{D}_{3}$ is converted to $25(\mathrm{OH}) \mathrm{D}_{3}$ by the enzyme, 25-hydroxlylase. In the kidney, the $25(\mathrm{OH}) \mathrm{D}_{3}$ is converted to the biologically active $1,25(\mathrm{OH})_{2} \mathrm{D}_{3}$ by the enzyme, 25-hydroxycalciferol 1- $\alpha$ hydroxylase (1- $\alpha$-hydroxylase) in the proximal convoluted tubule [1]. Dietary sources contain vitamin $\mathrm{D}_{3}$ and vitamin $\mathrm{D}_{2}$. Metabolism of vitamin $\mathrm{D}_{2}$ in the human body is the same as that of vitamin $\mathrm{D}_{3}$. In general, hydroxylated metabolites of vitamin $\mathrm{D}_{2}$ and vitamin $\mathrm{D}_{3}$ are simply referred to as $25(\mathrm{OH}) \mathrm{D}$ and $1,25(\mathrm{OH})_{2} \mathrm{D}$. It should be noted that

\footnotetext{
*Address correspondence to this author at the Department of Biochemistry and Molecular Medicine, The George Washington University School of Medicine and Health Sciences, 2300 Eye Street NW, Suite 530, Washington, DC 20037, USA; Tel: 202-994-5925; Fax: 202-994-8974;

E-mail: zyhan@gwu.edu

${ }^{\#}$ These authors contributed equally.
}

$1,25(\mathrm{OH})_{2} \mathrm{D}$ is the biologically active vitamin $\mathrm{D}$ and that the biological effect of $1,25(\mathrm{OH})_{2} \mathrm{D}$ on cells is mediated by the vitamin D receptor (VDR), a specific ligand-dependent nuclear transcription factor that regulates expression of a large number of genes in many organs including bone, muscle, pancreas, brain, the pituitary, and the immune system $[2,3]$.

The melanin pigment is an excellent natural absorbent of the UV-B radiation, and therefore dark-skinned people require substantially more exposure to UV-B rays than fair skinned people in order to synthesize an adequate amount of vitamin $\mathrm{D}_{3}[4,5]$. Thus, dark-skinned people, such as Blacks and dark skinned Indians, are more susceptible to developing vitamin D deficiency in the absence of adequate sunlight exposure or without taking vitamin D supplements [4-7]. The significance of adequate sunlight exposure for the vitamin D status in dark-skinned people is best illustrated by a recent finding showing that those Africans, such as the Maasai and Hadzabe people, who still maintain a hunter-gather life style and get plenty of sunlight exposure, have a serum level range of $25(\mathrm{OH}) \mathrm{D}$ at $43 \mathrm{ng} / \mathrm{mL}$ to $59 \mathrm{ng} / \mathrm{mL}$ [8], a concentration range that can only be found in sunlight-replete Caucasians lifeguards in the summer [9].

The conversion of $25(\mathrm{OH}) \mathrm{D}$ to $1,25(\mathrm{OH})_{2} \mathrm{D}$ by the $1-\alpha-$ hydroxylase in the kidney is strictly regulated (Fig. 1). The activity of $1-\alpha$-hydroxylase is stimulated primarily by 
parathyroid hormone (PTH) and inhibited by phosphate, $\mathrm{Ca}^{2+}$, and fibroblast growth factor 23 (FGF23). In addition, 1 - $\alpha$-hydroxylase is subjected to feedback inhibitory regulation by $1,25(\mathrm{OH})_{2} \mathrm{D}$. At high concentrations, $1,25(\mathrm{OH})_{2} \mathrm{D}$ induces inhibition of its own synthesis by downregulating 1- $\alpha$-hydroxylase activity in the kidney and activating vitamin D 24 hydroxylase in peripheral tissues (Fig. 1). The 24-hydroxylase hydroxylates both $25(\mathrm{OH}) \mathrm{D}$ and $1,25(\mathrm{OH})_{2} \mathrm{D}$ on the \#24-carbon to yield biologically inactive 24-hydroxyl derivatives, 24,25-dihydroxy-vitamin D $\left[24,25(\mathrm{OH})_{2} \mathrm{D}\right]$ and 1,24,25-trihydroxyvitamin D [1,24,25 $\left.(\mathrm{OH})_{3} \mathrm{D}\right][11,12]$. The combined actions of PTH, FGF23, $1,25(\mathrm{OH})_{2} \mathrm{D}, \mathrm{Ca}^{2+}$ and phosphate on the vitamin $\mathrm{D}$ metabolic enzymes lead to homeostasis of $1,25(\mathrm{OH})_{2} \mathrm{D}$, which is important for the maintenance of calcium and phosphate homeostasis in the blood.

The classical function of vitamin D is to regulate calcium and phosphorus homeostasis in the blood, which is critical for bone health. Thus, clinical determination of vitamin D status is largely based on the relationship between serum $25(\mathrm{OH}) \mathrm{D}$ level and bone disorders [13]. However, epidemiological studies have linked vitamin D deficiency with a plethora of negative health outcomes, including cardiovascular diseases, immune dysfunction, cancer, reproductive disorders, neurological disorders, and metabolic syndromes [13-16]. The action mechanism of the biologically active vitamin $\mathrm{D}, 1,25(\mathrm{OH})_{2} \mathrm{D}$, involves nuclear vitamin D receptor (VDR) which is ubiquitously expressed and acts as ligand-dependent transcription factor that regulates the promoters of vitamin $\mathrm{D}$ target genes via binding to the vitamin $\mathrm{D}$ responsive element (VDRE) in the promoters of these genes [17]. Most cell types in the human body appear to respond to $1,25(\mathrm{OH})_{2} \mathrm{D}$ stimulation, and a large number of the genes in the human genome are regulated by $1,25(\mathrm{OH})_{2} \mathrm{D}[2,3]$. In this context, it is frightening to see that up to $82.1 \%$ Blacks in the US are considered to be vitamin $\mathrm{D}$ deficient as defined by less than $20 \mathrm{ng} / \mathrm{mL} 25(\mathrm{OH}) \mathrm{D}$ in the serum [18]. Fortunately, there is no evidence of high rates of medical complications and symptomology of true vitamin D deficiency in the US Black population. What is going on? To understand it, we researched the MEDLINE databases to find studies, from 1967 to present, that directly compare between Blacks and Caucasians the following: serum vitamin D level, serum calcium level, serum parathyroid hormone level, bone mineral density and health, and non-skeletal risks associated with vitamin $\mathrm{D}$ deficiency. To our knowledge, this is the first attempt to systematically review the biomedical literature concerning specifically the vitamin D status in Blacks. In this review, we report on the available information and suggest that this pandemic vitamin D deficiency in the black population is a false alarm, because most Blacks of both genders and at all age groups have healthy serum levels of the biologically active $1,25(\mathrm{OH})_{2} \mathrm{D}$ and they are functionally vitamin $\mathrm{D}$ sufficient despite the fact that their serum $25(\mathrm{OH}) \mathrm{D}$ levels are in the deficient range.

\section{REVIEW OF EVIDENCE}

\section{Blacks Are Deficient in $25(\mathrm{OH}) \mathrm{D}$ but Replete with $1,25(\mathrm{OH})_{2} \mathrm{D}$}

In the blood circulation, up to $90 \%$ of $25(\mathrm{OH}) \mathrm{D}$ is bound to vitamin D-binding proteins (VDBP), the rest is mostly bound to albumin, and less than $1 \%$ remains free [10]. The $25(\mathrm{OH}) \mathrm{D}$ circulates in the blood at $\mathrm{ng} / \mathrm{mL}$ concentrations

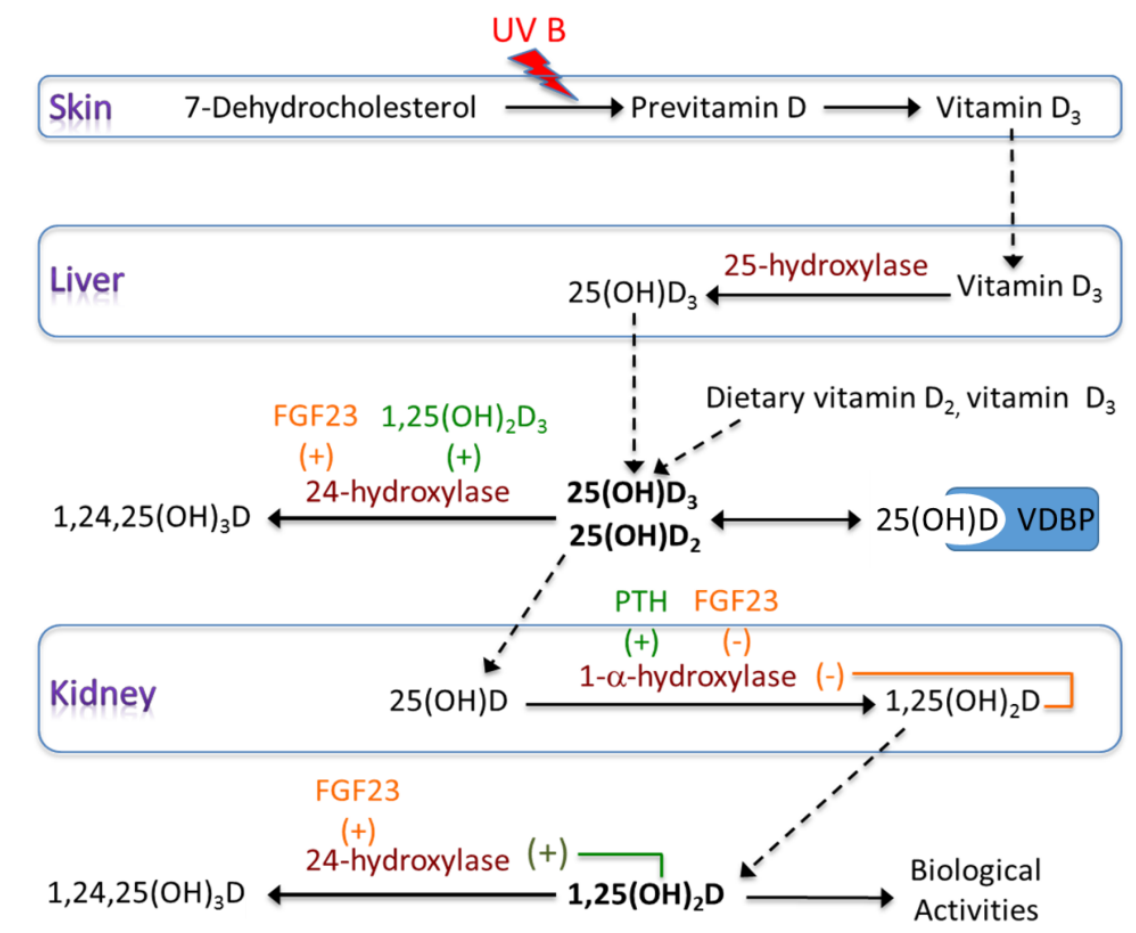

(+), stimulatory effect; (-), inhibitory effect; PTH, parathyroid hormone; FGF23, fibroblast growth factor 23

Fig. (1). Metabolism of vitamin d in human body. 
and has a half-life of approximately 15 days whereas the $1,25(\mathrm{OH})_{2} \mathrm{D}$ circulates at $\mathrm{pg} / \mathrm{mL}$ concentrations and has a half-life of approximately 15 hours [19-21]. Even though $1,25(\mathrm{OH})_{2} \mathrm{D}$ is the biologically active form of vitamin $\mathrm{D}$, determination of vitamin $\mathrm{D}$ status has been all about measuring the total serum levels of $25(\mathrm{OH}) \mathrm{D}$ for both technical convenience and the fact that the serum level of $25(\mathrm{OH}) \mathrm{D}$ is largely proportional to the serum level of $1,25(\mathrm{OH})_{2} \mathrm{D}$ in the general non-black population. The available studies have consistently demonstrated that many Blacks of both genders and at all life stages - neonates, preadolescents, adolescents, middle ages, and old ages have serum $25(\mathrm{OH}) \mathrm{D}$ levels in the ranges of deficiency (Table 1). However, studies that have directly compared the serum levels of both $25(\mathrm{OH}) \mathrm{D}$ and $1,25(\mathrm{OH})_{2} \mathrm{D}$ between Blacks and Caucasians consistently found that the serum $1,25(\mathrm{OH})_{2} \mathrm{D}$ level in Blacks is similar if not even slightly higher than that in Caucasians, notwithstanding the deficiencies of 25(OH)D (Table 1). These data indicate that Blacks are by large replete with the biologically active vitamin $\mathrm{D}$ and therefore are not functionally vitamin $\mathrm{D}$ deficient and that low serum 25(OH)D level in Blacks is not indicative of vitamin D deficiency.

\section{Bioavailability of Serum 25(OH)D in Blacks}

The commonly used assays that determine the concentrations of vitamin $\mathrm{D}$ in the serum measure total circulating $25(\mathrm{OH}) \mathrm{D}$ without distinguishing the free vitamin $\mathrm{D}$ from the vitamin $\mathrm{D}$ bound to vitamin $\mathrm{D}$ binding protein (VDBP) and albumin. Recently, Powe et al. [22] determined and compared the amounts of bioavailable $25(\mathrm{OH}) \mathrm{D}$ - that is, the amount of serum $25(\mathrm{OH}) \mathrm{D}$ not bound to VDBP between Blacks and Caucasians and found the following: (i) the amount of bioavailable serum $25(\mathrm{OH}) \mathrm{D}$ is proportional to the total amount of $25(\mathrm{OH}) \mathrm{D}$ in Caucasians; (ii) Blacks have vitamin $\mathrm{D}$ deficiency as defined by the low serum 25(OH)D level; (iii) Blacks have lower serum VDBP level than Caucasians; and (iv) the serum bioavailable 25(OH)D level in Blacks is similar to that of Caucasians after adjusting the VDBP-bound 25(OH)D. This study explains that one reason why Blacks have healthy levels of serum $1,25(\mathrm{OH})_{2} \mathrm{D}$ is because they have adequate levels of bioavailable 25(OH)D in the serum due to decreased serum VDBP level. Hence, it appears that although it is not necessary for Caucasians, a measurement of the serum $1,25(\mathrm{OH})_{2} \mathrm{D}$ level or the amount of the bioavailable $25(\mathrm{OH}) \mathrm{D}$ in the serum would more accurately determine vitamin D sufficiency or deficiency in the Black population. This is very important given the fact that these days taking high doses of oral vitamin D supplements is the norm of life for people who are diagnosed to be vitamin $\mathrm{D}$ deficient, and that excessive intake of vitamin D has the potential to cause chronic toxic effects of hypervitaminosis D, which presents as hypercalcemia and renal damage [23-25]. It is not unreasonable to think that treatment of the traditionally determined "vitamin D deficient" Blacks may cause a severe toxicity of hypervitaminosis D.

\section{PTH Status, Calcium Homeostasis and Bone Health in Blacks}

The classical function of $1,25(\mathrm{OH})_{2} \mathrm{D}$ is its ability to act in the intestine to stimulate the absorption of calcium and phosphorous, and in the kidney to stimulate the reabsorption of calcium and phosphorus. Thus, chronic deficiency of $1,25(\mathrm{OH})_{2} \mathrm{D}$ in the body due to various reasons, such as lossof-function mutations in 1- $\alpha$-hydroxylase deficiency and hypoparathyroidism, results in bone disorders, such as rickets, osteoporosis and osteomalacia. Elevation of the blood PTH level is a normal physiological response to

Table 1. Comparison of the mean blood levels of $25(\mathrm{OH}) \mathrm{D}, 1,25(\mathrm{OH})_{2} \mathrm{D}$, PTH, and calcium $\left(\mathrm{Ca}^{2+}\right)$ in caucasians and blacks.

\begin{tabular}{|c|c|c|c|c|c|c|c|c|c|}
\hline \multicolumn{2}{|c|}{$25(\mathrm{OH}) \mathrm{D}(\mathrm{ng} / \mathrm{mL})$} & \multicolumn{2}{|c|}{$1,25(\mathrm{OH})_{2} \mathrm{D}(\mathrm{pg} / \mathrm{mL})$} & \multicolumn{2}{|c|}{ PTH $(\mathrm{pg} / \mathrm{mL})$} & \multicolumn{2}{|c|}{ Serum $\mathrm{Ca}^{2+}(\mathrm{mM})$} & Subject Characteristics & Reference \\
\hline 29.9 & 18.5 & N/A & N/A & 36.6 & 40.9 & N/A & N/A & Peripubertal females & [44] \\
\hline 27.16 & 13.1 & N/A & N/A & 35.9 & 39 & N/A & N/A & Adult females & [46] \\
\hline 31.2 & 14.8 & N/A & N/A & 38.89 & 47.08 & 4.125 & 2.29 & Adult females & [48] \\
\hline 18.4 & 10.8 & 37.31 & 40.38 & 23.58 & 35.83 & 2.32 & 2.29 & Adult males and females & [34] \\
\hline 25.5 & 13.8 & 28.43 & 28.03 & 30.27 & 37.15 & 1.20 & 1.21 & Adult females & [33] \\
\hline 17.41 & 11.71 & 31.45 & 32.22 & N/A & N/A & N/A & N/A & Neonates & [47] \\
\hline 32.6 & 20.4 & N/A & N/A & N/A & N/A & N/A & N/A & Adult males & {$[22]$} \\
\hline 39.54 & 16.23 & N/A & N/A & N/A & N/A & N/A & N/A & Adolescent females & [45] \\
\hline
\end{tabular}

The details of the statistical analysis of the data shown here can be found in the original studies. N/A: not available

Normal PTH levels: $15-60 \mathrm{pg} / \mathrm{ml}$

Normal calcium levels: $2.0-2.6 \mathrm{mM}$ 
decreased calcium level in the blood. The primary functions of PTH include stimulation of bone resorption by osteoclasts to release calcium from the bone and stimulation of $1-\alpha$ hydroxylase in the kidney to increase the production of $1,25(\mathrm{OH})_{2} \mathrm{D}$, which in turn stimulates intestinal absorption of calcium and renal reabsorption of calcium.

In comparison to the serum PTH level in Caucasians, the serum PTH level in Blacks are approximately $15 \%$ higher, a common findings in different studies (Table 1). However, the serum $\mathrm{Ca}^{2+}$ level in Blacks is in the normal range and virtually identical to that of Caucasians (Table 1), indicating that the elevated serum PTH level in Blacks is not indicative of clinical hyperparathtyroidism because hypercalcemia normally occurs as a result of hyperparathyroidism [26-28].

Although high serum PTH level increases the risk of accelerated rate of bone resorption and bone disorders in Caucasians, the higher serum PTH level in Blacks actually does not seem to cause bone disorders. As a matter of fact, Blacks actually have higher bone mass density (BMD), higher bone strength and less risk of bone fracture than Caucasians as shown in studies conducted by DawsonHughes et al. [29] and Hochberg [30]. For example, the risk that a postmenopausal Caucasian woman having a hip fracture by age 80 is $11 \%$ compared with only $4 \%$ for a Black woman [31, 32]. Apparently, the higher PTH level does not cause faster bone turnover in Blacks possibly as a result of bone resistance to PTH [33, 34]. This bone resistance to PTH is likely to be beneficial to the health of the skeletal system in Blacks since it prevents PTH from overly stimulating bone resorption when serum PTH level is high. Nevertheless, the relationship between serum PTH level and vitamin D metabolism seems greatly different between Blacks and Caucasians [35].

\section{Effect of 1,25(OH $)_{2}$ D on Serum PTH Level in both Blacks and Caucasians}

True vitamin D deficiency can decrease the serum calcium level, which in turn can cause secondary hyperparathyroidism and increased bone resorption [27]. Thus, the increase of serum PTH level is a normal compensatory mechanism in response to a decreasing serum calcium concentration. But, why do Blacks have elevated serum PTH level and yet their serum levels of $\mathrm{Ca}^{2+}$ are within the normal range? The answer to this question is provided by a study involving female Black and Caucasian subjects matched with ages and body-mass index. In this study, the subjects received $0.25 \mu \mathrm{g} 1,25(\mathrm{OH})_{2} \mathrm{D}$ four times a day for 2 weeks. At the end of this study, it was found that the treatment virtually had no effect on the serum levels of $25(\mathrm{OH}) \mathrm{D}$ and $\mathrm{Ca}^{2+}$, it increased the serum $1,25(\mathrm{OH})_{2} \mathrm{D}$ level, and it significantly decreased the serum PTH level in all subjects (Table 2) [29]. Furthermore, this study demonstrated that the treatment caused the average serum levels of $1,25(\mathrm{OH})_{2} \mathrm{D}$ in these female Caucasians and Blacks to be increased to an almost identical level $(40.54 \pm 3.65$ $\mathrm{pg} / \mathrm{mL}$ in Caucasians vs $41.73 \pm 3.85 \mathrm{pg} / \mathrm{mL}$ in Blacks), and yet the post treatment level of PTH still remained higher in Blacks than in Caucasians: the pretreatment PTH levels are $31.7 \pm 3.8 \mathrm{pg} / \mathrm{mL}$ in Caucasians vs $48.1 \pm 4.0 \mathrm{pg} / \mathrm{mL}$ in Blacks and the post treatment PTH levels are $23.4 \pm 3.6$ $\mathrm{pg} / \mathrm{mL}$ in Caucasians vs $33.9 \pm 3.7 \mathrm{pg} / \mathrm{mL}$ in Blacks (Table 2). These findings demonstrated two important points: first, these Black women maintain a higher level of serum PTH than Caucasian women do even when their serum $1,25(\mathrm{OH})_{2} \mathrm{D}$ levels are almost identical; second, changes in the serum levels of PTH is unrelated to the status of calcium and $25(\mathrm{OH}) \mathrm{D}$ but directly related to the $1,25(\mathrm{OH})_{2} \mathrm{D}$ level in the blood. Since PTH directly affects the production of $1,25(\mathrm{OH})_{2} \mathrm{D}$ in the kidney by increasing the level of renal $1 \alpha$-hydroxylase [36] and since $1,25(\mathrm{OH})_{2} \mathrm{D}$ can directly induce suppression of the expression of PTH gene in and secretion of PTH from the human parathyroid glands [37], it is plausible that there is a $\mathrm{Ca}^{2+}$-independent $1,25(\mathrm{OH})_{2} \mathrm{D} \rightarrow$ PTH regulatory loop that regulates the serum $1,25(\mathrm{OH})_{2} \mathrm{D}$ level. Thus, PTH would stimulate 1- $\alpha$-hydroxylase for $1,25(\mathrm{OH})_{2} \mathrm{D}$ synthesis and at high concentrations, $1,25(\mathrm{OH})_{2} \mathrm{D}$ would exert a feedback inhibitory effect on the expression of PTH gene in and secretion of PTH from the parathyroid glands in a $\mathrm{Ca}^{2+}$-independent manner. However, there is likely a caveat about this $1,25(\mathrm{OH})_{2} \mathrm{D} \rightarrow$ PTH loop in Blacks - that is, like the bone resistance to PTH [33, 34], there could also be kidney resistance to PTH in Blacks. Such a kidney desensitization to PTH can explain why the serum PTH level in Blacks is higher than that in Caucasians even when the $1,25(\mathrm{OH})_{2} \mathrm{D}$ levels are almost identical in both groups because higher levels of PTH are needed to maintain an adequate level of the 1- $\alpha$-hydrolylase in the kidney to maintain sufficient amount of 1- $\alpha$-hydroxlylase for the synthesis of the same amount of $1,25(\mathrm{OH})_{2} \mathrm{D}$ in the bodies of Blacks. However, future research involving more subject and subjects of both genders and at different age groups is needed to investigate this possibility.

Table 2. Effects of $1,25(\mathrm{OH})_{2} \mathrm{D}$ treatment on the serum levels of $25(\mathrm{OH}) \mathrm{D}, 1,25(\mathrm{OH})_{2} \mathrm{D}$, PTH, and calcium $\left(\mathrm{Ca}^{2+}\right)$ in adult female caucasians and blacks.

\begin{tabular}{|c|c|c|c|c|c|c|c|c|c|}
\hline \multirow[t]{2}{*}{ Conditions } & \multicolumn{2}{|c|}{$25(\mathrm{OH}) \mathrm{D}(\mathrm{ng} / \mathrm{mL})$} & \multicolumn{2}{|c|}{$1,25(\mathrm{OH})_{2} \mathrm{D}(\mathrm{pg} / \mathrm{mL})$} & \multicolumn{2}{|c|}{ PTH (pg/mL) } & \multicolumn{2}{|c|}{ Serum $\mathrm{Ca}^{2+}(\mathrm{mM})$} & \multirow{2}{*}{$\begin{array}{c}\text { Refere } \\
\text { nce }\end{array}$} \\
\hline & Caucasian & Blacks & Caucasian & Blacks & Caucasian & Blacks & Caucasian & Blacks & \\
\hline $\begin{array}{c}\text { Before } \\
\text { treatment }\end{array}$ & $35.4( \pm 3.7)$ & $19.8( \pm 3.9)$ & $30.08 \underline{(+2.38)}$ & $36.81( \pm 2.46)$ & $31.7( \pm 3.8)$ & $48.1( \pm 4.0)$ & $2.24( \pm 0.02)$ & $2.21( \pm 0.02)$ & \multirow{2}{*}{ [29] } \\
\hline $\begin{array}{c}\text { After } \\
\text { treatment }\end{array}$ & $38.7( \pm 4.9)$ & $21.7( \pm 5.2)$ & $40.54( \pm 3.65)$ & $41.73( \pm 3.85)$ & $23.4( \pm 3.6)$ & $33.9( \pm 3.7)$ & $2.27( \pm 0.02)$ & $2.23( \pm 0.02)$ & \\
\hline
\end{tabular}

Normal PTH levels: $15-60 \mathrm{ng} / \mathrm{ml}$

Normal calcium levels: $2.0-2.6 \mathrm{mM}$ 
Vitamin D Status and the Risks of Non-skeletal Diseases in the Black Population

Various epidemiological studies have associated low serum $25(\mathrm{OH}) \mathrm{D}$ level with negative health outcomes in the general population [13-16]. In addition to causing bone disorders, vitamin D deficiency is also associated with increased risks of developing stroke, coronary heart disease, premenstrual syndrome, chronic kidney disease, and systolic high blood pressure in Caucasians (Table 3). However, direct comparison between Caucasians and Blacks indicate that Blacks are relatively protected from the numerous clinical complications of the non-skeletal systems (Table $\mathbf{3}$ ).

\section{DISCUSSION}

In general, vitamin $\mathrm{D}$ deficiency is defined as the serum level of $25(\mathrm{OH}) \mathrm{D}$ lower than $20 \mathrm{ng} / \mathrm{mL}$ and closely associated with clinical bone disorders, such as rickets, osteomalacia and osteoporosis. However, this classification of vitamin D deficiency is most unlikely to be applicable to Blacks because they have healthy serum levels of the biologically active $1,25(\mathrm{OH})_{2} \mathrm{D}$ and calcium at all life stages despite the fact that their serum $25(\mathrm{OH}) \mathrm{D}$ level is in the range of deficiency. Blacks also do not present with high rates of the various skeletal and non-skeletal clinical complications associated with true vitamin D deficiency (Tables 1 and 3). Therefore, the low serum 25(OH)D level and normal serum $1,25(\mathrm{OH})_{2} \mathrm{D}$ level in Blacks are indicative of functional vitamin D sufficiency. This feature is rather unique to Blacks because the serum 25(OH)D level is proportional to the serum level of $1,25(\mathrm{OH})_{2} \mathrm{D}$ and deficiency of $25(\mathrm{OH}) \mathrm{D}$ is indicative of functional vitamin $\mathrm{D}$ deficiency in people of other races. For instance, the high rate of vitamin D deficiency in the Indian population is closely associated with high incidences of bone disorders [50]. Nevertheless, we believe determination of the vitamin D status in Blacks in the future should use test results that show the serum levels of bioavailable $25(\mathrm{OH}) \mathrm{D}$ and $1,25(\mathrm{OH})_{2} \mathrm{D}$.

A study by Signorello et al. determined serum 25(OH)D level of an African American population in the context of the African ancestry based on the analysis of a panel of 276 ancestry informative SNPs found that, with increasing African ancestry, there is a linear statistically significant decrease in the serum level of 25(OH)D [38]. In this study, individuals with high African ancestry, (>95\%) have 16.5 $\mathrm{ng} / \mathrm{mL} 25(\mathrm{OH}) \mathrm{D}$ whereas people with lower African ancestry, $(<85 \%)$ have 1.2 times more circulating $25(\mathrm{OH}) \mathrm{D}$. It is most likely that the evolution of African people has selected an adaptive compensatory mechanism to cope with a reduced synthesis of previtamin $\mathrm{D}$ in the skin due to skin hyperpigmentation that reduces the amount of UV-B radiation that could reach the epidermis [5, 39]. This compensatory mechanism maximizes the synthesis and maintenance of optimal serum levels of $1,25(\mathrm{OH})_{2} \mathrm{D}$ in the face of low serum 25(OH)D level. The outcome is successful maintenance of calcium homeostasis and the health of the skeletal system as well as the non-skeletal systems. It is most likely that the evolution of this mechanism has involved the selection of multiple changes. First, there is the lowering of the concentrations of VDBP in the blood to increase the bioavailability of $25(\mathrm{OH}) \mathrm{D}$ for the synthesis of $1,25(\mathrm{OH})_{2} \mathrm{D}$ [22]. Second, there is elevation of the serum PTH to high enough levels to perhaps stimulate and maintain high amounts of 1- $\alpha$-hydrolylase in the kidney for the synthesis of adequate amounts of $1,25(\mathrm{OH})_{2} \mathrm{D}$. Yet, the levels of PTH are not too high to causes bone resorption and complications of hyperparathyroidism. Third, the 24-hydroxylase catalyzes the conversion of $1,25(\mathrm{OH})_{2} \mathrm{D}$ into the inactive intermediate $1,24,25(\mathrm{OH})_{3} \mathrm{D}[12]$. The 24-hydroxylase gene is normally expressed at very low level, but its expression is strongly upregulated by $1,25(\mathrm{OH})_{2} \mathrm{D}[40]$. It has been demonstrated that a unique variant of the vitamin $\mathrm{D}$ responsive element (VDRE) that weakens the transcriptional activity of the promoter of the 24-hydroxylase gene exists in the Black population [41]. The consequence of the presence of this variant is that the expression of the 24-hydroxylase gene is not so robust even in the presence of high concentrations of $1,25(\mathrm{OH})_{2} \mathrm{D}$ [41]. This change ensures slower rate of inactivation of $1,25(\mathrm{OH})_{2} \mathrm{D}$ in Blacks.

\section{CONCLUSION}

In summary, it is critical to investigate why Blacks are able to maintain a healthy serum $1,25(\mathrm{OH})_{2} \mathrm{D}$ level at all life stages despite the fact that they have deficient $25(\mathrm{OH}) \mathrm{D}$ level (Table 1). Accurate determination of vitamin D status in Blacks will be beneficial for the management of their overall health since true vitamin D deficiency is correlated to, if not the cause of, a long list of negative health outcomes, including premature mortality, cancers, autoimmune diseases, diabetes, chronic musculoskeletal pain, neurological and cognitive disorders, depression, dental

Table 3. Relationship between various disease risk and low levels of $25(\mathrm{OH}) \mathrm{D}$ in caucasians and blacks.

\begin{tabular}{|c|c|c|c|}
\hline \multirow{2}{*}{ Diseases } & \multicolumn{2}{|c|}{ Risk Associated with Low 25(OH)D Level } & Blacks \\
\cline { 2 - 4 } & Caucasian & No apparent association & No apparent association \\
\hline Stroke & Increased risk & No apparent association & {$[51]$} \\
\hline CHD & Increased risk & No apparent association & {$[53]$} \\
\hline PMS & No apparent association & No apparent association & {$[54]$} \\
\hline CKD & Increased fatality & [55] \\
\hline HBP & Increased risk & & [53] \\
\hline
\end{tabular}

CHD: Coronary Heart Disease; PMS: Premenstrual Syndrome; CKD: Chronic Kidney Disease; HBP: systolic High Blood Pressure. 
disease and cardiovascular disease [42, 43]. It is therefore of utmost importance that future research be focused on better understanding of the mechanisms that regulate metabolism of vitamin $\mathrm{D}$ and maintain a healthy serum $1,25(\mathrm{OH})_{2} \mathrm{D}$ level in Blacks.

\section{CONFLICT OF INTEREST}

The authors declare that there is no conflict of interest that would cause the impartiality of this review.

\section{ACKNOWLEDGEMENTS}

The authors wish to thank the Department of Biochemistry and Molecular Medicine, The George Washington University School of Medicine and Health Sciences for support.

\section{REFERENCES}

[1] Bringhurst FR, Demay MB, Krane SM, Kronenberg HM. Bone and mineral metabolism in health and disease. In: Longo DL, Fauci AS, Kasper DL, Hauser SL, Jameson JL, Loscalzo J, Eds. Harrison's principles of internal medicine $18^{\text {th }}$ ed. New York, NY: McGrawHill 2012; p. 3082.

[2] Bouillon R, Carmelist G, Verlinden L, et al. Vitamin D and human health: Lessons from vitamin D receptor null mice. Endocin Rev 2008; 29: 726-76.

[3] Carlberg C. Genome-wide (over)view on actions of vitamin D. Front Physiol 2014; 5: 167.

[4] Norman AW. Sunlight, season, skin pigmentation, vitamin D and 25-hydroxyvitamin D: Integral components of the vitamin D endocrine system. Am J Clin Nutr 1998; 67: 1108-10.

[5] Clemens T, Adams J, Henderson S, Holick MF. Increased skin pigment reduces the capacity of skin to synthesise vitamin $\mathrm{D}_{3}$. The Lancet 1986; 1: 74-6.

[6] Nesby-O'Dell S, Scanlon KS, Cogswell ME, et al. Hypovitaminosis D prevalence and determinants among African American and white women of reproductive age: $3^{\text {rd }}$ National Health and Nutrition Examination Survey, 1988-1994. Am J Clin Nutr 2002; 76: 187-92.

[7] Moore C, Murphy M, Holick MF. Vitamin D intakes by children and adults in the United States differ among ethnic groups. J Nutr 2005; 135: 2478-85.

[8] Luxwolda M, Kuipers R, Kema I, Dijck-Brouwer D, Muskiet F. Traditionally living populations in East Africa have a mean serum 25-hydroxyvitamin D concentration of $115 \mathrm{nmol} / \mathrm{l}$. Br J Nutr 2012; 108: $1557-61$.

[9] Better O, Shabtai M, Kedar S, Melamud A, Berenheim J, Chaimovitz C. Increased incidence of nephrolithiasis (N) in lifeguards (LG) in Israel. Adv Exp Med Bio 1980; 128: 467-72.

[10] Bikle DD, Gee E, Halloran B, Kowalski MA, Ryzen E, Haddad JG. Assessment of the free fraction of 25-hydroxyvitamin D in serum and its regulation by albumin and the vitamin D-binding protein. $\mathbf{J}$ Clin Endocrinol Metab 1986; 63: 954-9

[11] Makin G, Lohnes D, Byford V, Ray R, Jones G. Target cell metabolism of 1,25-dihydroxyvitamin D3 to calcitroic acid. Evidence for a pathway in kidney and bone involving 24-oxidation. Biochem J 1989; 262; 173-80.

[12] Reddy G, Tserng K. Calcitroic acid, end product of renal metabolism of 1,25-dihydroxyvitamin D3 through C-24 oxidation pathway. Biochemistry 1989; 28: 1763-9.

[13] Holick MF. Vitamin D deficiency. N Eng J Med 2007; 357: 26681.

[14] Adams J, Hewison M. Update in vitamin D. J Clin Endocrin Metab 2010; 95: 471-8

[15] Melamed M, Michos E, Post W, Astor B. 25-hydroxyvitamin D levels and the risk of mortality in the general population. Arch Intern Med 2008: 168: 1629-37

[16] Wang TJ, Pencina MJ, Booth SL, et al. Vitamin D deficiency and risk of cardiovascular disease. Circulation 2008; 117: 503-11.
[17] Haussler M. Vitamin D receptor: Molecular signaling and actions of nutritional ligands in disease prevention. Nutr Rev 2008; 66: S98-112.

[18] Forrest K, Stuhldreher WL. Prevalence and correlates of vitamin D deficiency in US adults. Nutr Res 2011; 31: 48-54.

[19] Jones G. Pharmacokinetics of vitamin D toxicity. Am J Clin Nutr 2008; 88: 582S-6.

[20] Levine B, Singer F, Bryce G, Mallon J, Miller O, Coburn J. Pharmacokinetics and biologic effects of calcitriol in normal humans. J Lab Clin Med 1985; 105: 239-46.

[21] Fakih M. A phase I pharmacokinetic and pharmacodynamic study of intravenous calcitriol in combination with oral gefitinib in patients with advanced solid tumors. Clin Cancer Res 2007; 13 1216-23.

[22] Powe C, Evans MK, Wenger J, et al. Vitamin D-binding protein and vitamin D status of black Americans and white Americans. N Eng J Med 2013; 369: 1991-2000.

[23] O'Connor M, Thoreson C, Ramsey N, Ricks M, Sumner A. The uncertain significance of low vitamin D levels in African descent populations: A review of the bone and cardiometabolic literature. Prog Cardiovasc Dis 2013; 56: 261-9.

[24] Vogiatzi M, Jacobson-Dickman E, DeBoer M. Drugs, and therapeutics committee of the pediatric endocrine society. vitamin D supplementation and risk of toxicity in pediatrics: A review of current literature. J Clin Endocrinol Metab 2014; 99: 1132-41.

[25] Vieth R. Vitamin D toxicity, policy, and science. J Bone Miner Res 2007; 22: V64-8.

[26] Silverberg SJ. Natural history of primary hyperparathyroidism. Endocrinol Metab Clinics North Am 2000; 29: 451-64.

[27] Sai A, Walters R, Fang X, Gallagher J. Relationship between vitamin $\mathrm{D}$, parathyroid hormone, and bone health. J Clin Endocrinol Metab 2011; 96: E436-46.

[28] Bilezikian J, Potts JT Jr, Fuleihan Gel-H, et al. Summary statement from a workshop on asymptomatic primary hyperparathyroidism: A perspective for the $21^{\text {st }}$ century. J Bone Miner Res 2002; 17: N211.

[29] Dawson-Hughes B, Harris S, Finneran S, Rasmussen H. Calcium absorption responses to calcitriol in black and white premenopausal women. J Clin Endocrinol 1995; 80: 3068-72.

[30] Hochberg MC. Racial differences in bone strength. Trans Am Clin Climatol Asso 2007; 118: 305-15

[31] Barrett J, Baron J, Karagas M, Beach M. Fracture risk in the U.S. Medicare population. J Elic Epidem 1999; 52: 243-9.

[32] Bohannon A, Hanlon J, Landerman R, Gold D. Association of race and other potential risk factors with nonvertebral fractures in community-dwelling elderly women. Am J Epidem 1999; 149: 1002-9.

[33] Cosman F, Morgan DC, Nieves JW, et al. Resistance to bone resorbing effects of PTH in black women. J Bone Miner Res 1997; 12: $958-66$

[34] Fuleihan G, Gundberg CM, Gleason R, et al. Racial differences in parathyroid hormone dynamics. J Clin Endocrinol Metab 1994; 79: 1642-7.

[35] Wright N, Chen L, Niu J, et al. Defining physiologically "normal" vitamin D in African Americans. Osteoporos Int 2012; 23: 2283 91.

[36] Armbrecht HJ, Wongsurawat N, Zenser TV, Davis BB. Effect of PTH and 1,25-(OH)2D3 on renal 25(OH)D3 metabolism, adenyl cyclase, and protein kinase. Am J Physiol 1984; 246: E102-7.

[37] Delmez JA, Tindira C, Grooms P, Dusso A, Windus DW, Slatopolsky E. Parathyroid hormone suppression by intravenous 1,25-dihydroxyvitamin D. A role for increased sensitivity to calcium. J Clin Invest 1989; 83:1349-55.

[38] Signorello L, Williams SM, Zheng W, et al. Blood vitamin d levels in relation to genetic estimation of African ancestry. Cancer Epidemiol Biomarks Prev 2010; 19: 2325-31.

[39] Gallagher J, Peacock M, Yalamanchili V, Smith L. Effects of vitamin D supplementation in older African American women. J Clin Endocrinol Metab 2013; 98: 1137-46.

[40] Shimada T, Yamazaki Y, Takahashi M, et al. Vitamin D receptorindependent FGF23 actions in regulating phosphate and vitamin D metabolism. Am J Physiol Renal Physiol 2005; 289: F1088-95.

[41] Roff A, Wilson R. A novel SNP in a vitamin D response element of the CYP24A1 promoter reduces protein binding, transactivation, and gene expression. J Steroid Biochem Mol Biol 2008; 112: 4754 . 
[42] Hossein-nezhad A, Holick MF. Vitamin D for health: a global perspective. Mayo Clin Proc 2013; 88: 720-55.

[43] Spedding S, Vanlint S, Morris H, Scragg R. Does vitamin D sufficiency equate to a single serum 25-hydroxyvitamin D level or are different levels required for non-skeletal diseases? Nutrition 2013; 5: 5127-39.

[44] Hanks L, Ashraf A, Alvarez J, Beasley T, Fernandez J, Casazza K. BMI but not race contributes to vitamin D-parathyroid hormone axis in peripubertal girls. Infant Child Adolesc Nutr 2013; 5: 100-5.

[45] Dong Y, Pollock N, Stallmann-Jorgensen IS, et al. Low 25hydroxyvitamin D levels in adolescents: Race, season, adiposity, physical activity, and fitness. Pediatrics 2010; 125: 1104-11.

[46] Aloia J, Chen D, Chen H. The 25(OH)D/PTH threshold in black women. J Clin Endocrinol Metab 2010; 95: 5069-73.

[47] Eichholzer M, Platz EA, Bienstock JL, et al. Racial variation in vitamin D cord blood concentration in white and black male neonates. Cancer Causes Contr 2013; 24: 91-8.

[48] Cosman F, Shen V, Morgan D, et al. Biochemical responses of bone metabolism to 1,25-dihydroxyvitamin $\mathrm{D}$ administration in black and white women. Osteoporo Int 2000; 11: 271-7.

[49] Weaver C, McCabe LD, McCabe GP, et al. Vitamin D status and calcium metabolism in adolescent black and white girls on a range of controlled calcium intakes. J Clin Endocrinol Metab 2008; 93: 3907-14.

[50] Ritu G, Gupta A. Vitamin D deficiency in India: Prevalence, causalities and interventions. Nutrients 2014; 6: 729-75.

[51] Michos ED, Reis JP, Post WS, et al. 25-Hydroxyvitamin D deficiency is associated with fatal stroke among whites but not blacks: The NHANES-III linked mortality files. Nutrition 2012; 28: 367-71.

[52] Robinson-Cohen C, Hoofnagle AN, Ix JH, et al. Racial differences in the association of serum 25-hydroxyvitamin D concentration with coronary heart disease events. JAMA 2013; 310: 179-88.

[53] Bertone-Johnson ER, Hankinson SE, Forger NG, et al. Plasma 25hydroxyvitamin D and risk of premenstrual syndrome in a prospective cohort study. BMC Womens Health 2014: 14: 56.

[54] Jorgetti, V, dos Reis LM, Ott SM. Ethnic differences in bone and mineral metabolism in healthy people and patients with CKD. Kidney Int 2013; 85: 1283-9.

[55] Sakamoto R, Jaceldo-Siegl K, Haddad E, Oda K, Fraser GE, Tonstad S. Relationship of vitamin D levels to blood pressure in a biethnic population. Nutr Metab Cardiovasc Dis 2013; 23: 776-84.

(C) Roberts et al,; Licensee Bentham Open.

This is an open access article licensed under the terms of the Creative Commons Attribution Non-Commercial License (http://creativecommons.org/licenses/ by-nc/3.0/) which permits unrestricted, non-commercial use, distribution and reproduction in any medium, provided the work is properly cited. 